\begin{tabular}{c} 
OSOBA $\boldsymbol{\| \text { Wina }}$ \\
Filozofia Chrześcijańska $\bullet$ Tom 9, Poznań 2012 \\
Uniwersytet im. Adama Mickiewicza w Poznaniu $\bullet$ Wrdziat Teologiczny \\
\hline
\end{tabular}

ZBIGNIEW JANUSZEWSKI

\title{
Ludzka potrzeba prawdy jako nadzieja wobec "pękniętego świata" w refleksji Gabriela Marcela
}

The Human Need for Truth as Hope for a Broken World in the Reflection of Gabriel Marcel

Gabriel Marcel urodził się 7 grudnia 1889 roku w Paryżu. Jego dzieciństwo zostało boleśnie naznaczone śmiercią matki. Zmarła, kiedy chłopiec ukończył cztery lata. Uczęszczał do renomowanego liceum, a następnie podjął studia na Sorbonie. Mając 21 lat, zdał tam egzamin państwowy z filozofii, co umożliwiło mu nauczanie tegoż przedmiotu w liceach. Wykładał we francuskim Sens, Paryżu i Montpelier. W czasie I wojny światowej Marcel z powodu zbyt słabego zdrowia nie został wcielony do armii. Pracował natomiast w jednym z oddziałów Czerwonego Krzyża, zajmując się zbieraniem informacji o zaginionych żołnierzach i dostarczaniem tychże wiadomości zainteresowanym rodzinom. Praca ta, będąca osobistym i bliskim spotkaniem z ludzką tragedią, odbiła się także w jego refleksji filozoficznej. W 1929 roku, dokładnie 23 marca, w sobotę Marcel przyjął chrzest w Kościele katolickim. „Zostałem ochrzczony dzisiaj rano - pisał w swoim dzienniku - mój stan wewnętrzny był lepszy, niż ośmieliłbym się sobie tego życzyć; bez zachwytów, tylko spokojny, zrównoważony oraz pełny nadziei i wiary". Wspomina się o tym w większości not biograficznych, gdyż z pewnością było to bardzo istotne wydarzenie w jego życiu osobistym.

Oprócz z założenia niesystematycznego uprawiania filozofii Marcel zajmował się także dramaturgią. Pisał sztuki teatralne, był krytykiem w jednym z czasopism francuskich oraz redaktorem katolickiego wydawnictwa Plon. Za swoją twórczość otrzymał nagrodę Akademii Francuskiej, był także człon-

\footnotetext{
${ }^{1}$ G. Marcel, Być i mieć, thum. D. Eska, Warszawa 2001, s. 154.
} 
kiem francuskiego towarzystwa naukowego - Instytutu Francji. W latach 1949-1950 prowadził wykłady poświęcone myśli Adama Gifforda na uniwersytecie w Aberdeen. Warto wspomnieć także o dużej roli muzyki w życiu tego filozofa. „W końcu - wspominał Marcel - jest to dla mnie dzisiaj bardzo wyraźne, że Jan Sebastian Bach był w moim życiu tym, czym ani Pascal, ani święty Augustyn, ani żaden inny duchowy pisarz nigdy w tym życiu nie był"'. Gabriel Marcel zmarł w Paryżu 8 października 1973 roku.

Do najważniejszych jego dzieł filozoficznych należą: Dziennik metafizyczny oraz jego druga część Być i mieć, Od wezwania do sprzeciwu, Homo viator, Tajemnica bytu, Człowiek problematyczny, Obecność i nieśmiertelność.

\section{ZłAMANY ŚWIAT ${ }^{3}$}

Gabriel Marcel, jak się zdaje, był tym, który wprowadził na scenę filozoficzną pojęcie złamanego świata. Tak nazywa się również jedna z jego sztuk. Jej bohaterka, Christiane, wypowiada tam następujące słowa:

Czy nie masz czasem wrażenia, że żyjemy..., jeżeli można nazywać to życiem... w złamanym świecie? Tak, złamanym jak zepsuty zegarek. Sprężyna przestała działać. Na pozór nic się nie zmieniło. Wszystko jest na swoim miejscu. Ale gdy przyłożysz zegarek do ucha, nie usłyszysz już nic. Rozumiesz, to, co nazywamy światem, ludzkim światem... dawniej musiało mieć serce, ale można by powiedzieć, że to serce przestało bić ${ }^{4}$.

W utworze dramatycznym jednak inaczej podchodzi się do zagadnień niż na płaszczyźnie filozofii. Na scenie aktorka może wypowiedzieć piękną metaforę, że oto serce świata przestało bić. Widzowie w teatrze zaś pod wpływem tej frazy, być może, nawet doznają wzruszenia. Do filozofii jednak należy przemyślenie tej metafory, zanalizowanie podstaw, na bazie których mogła ona $\mathrm{w}$ ogóle powstać w ludzkim umyśle. Czy taki osąd świata jest z gruntu uczciwy, czyli czy nasz ludzki świat jest złamany naprawdę?

$\mathrm{Z}$ wielu dostępnych znaczeń pojęcia świat Christiane w swojej wypowiedzi wykreśliła jedynie świat ludzki. To on ma jakąś wewnętrzną skazę. W analizie pękniętego świata zatem musi chodzić przede wszystkim o społeczeństwo i o osobę ludzką, których egzystencja została dotknięta swego rodzaju parali-

\footnotetext{
${ }^{2}$ G. Marcel Music and philosophy, trans. S. Maddux, R.E. Wood, Milwaukee 2005, s. 41.

${ }^{3}$ W literaturze można się spotkać również z thumaczeniami: „,rozbity świat”, ,pęknięty świat”.

${ }^{4}$ G. Marcel Tajemnica bytu, thum. M. Frankiewicz, Kraków 1995, s. 46.
} 
żem. Owa wewnętrzna niemoc jednak, choć należy głównie do ludzkiego świata, rozlewa się także poprzez człowieka na całe uniwersum. Nadzieją może napełnić fakt, że w niektórych wypadkach ludzie są jeszcze na tyle wrażliwi, by taki defekt odczuć.

„Istnieje wymiar - można przeczytać u Marcela, - w którym świat nie ma sensu. Więcej, w tym wymiarze zadawać sobie pytanie, czy świat ma jakikolwiek sens, byłoby sprzecznością samą w sobie" ${ }^{5}$. Wymiar ten jest miejscem szczególnym oczywiście w negatywnym sensie tego słowa. W nim to człowiek traci nie tylko aktualne poczucie sensu egzystencji, ale zamknięta zostaje przed nim jakakolwiek możliwość jego zaistnienia. Mówiąc symbolicznie, bramy i okna świata w tym wymiarze, których zadaniem mogłoby być skądinąd wpuszczanie światła, zostały zatrzaśnięte na zawsze. Ludzie tam przebywający zostali skazani wyłącznie z powodu przebywania w nim na dotkliwe i wieczne poczucie bezsensu. Wymiar ten dotyka wielu przestrzeni człowieczego bytowania, zanieczyszcza źródła, z których człowiek od niepamiętnych czasów czerpał nadzieję i sens bycia. Istnieje tu jednakże wskazówka, mówiąca, że jest to wymiar, a zatem nie całość ludzkiego świata. Już u początków refleksji można więc zasadnie domniemywać, że pomimo całego dramatyzmu pękniętego świata możemy mieć nadzieję.

Przed podjęciem próby jej przedstawienia trzeba z konieczności poddać refleksji ową ciemną, nieprzyjazną ludziom rzeczywistość. Wydaje się zasadne domniemanie, że u jej podstaw kryje się tajemnicza postać zła. Czasem w dniach szczególnej na nie wrażliwości - pokazuje ono niektórym swe straszliwe oblicze.

Wszyscy znamy chwile - pisał o jednym z takich dni Marcel - kiedy wszystko budzi w nas pokusę rozpaczy [...]. Nie należy jednak sądzić, by chwile takie były jedynie chwilami zniechęcenia i utraty odwagi. Stają się one chwilami bezlitośnie przytomnego i przenikliwego widzenia świata. W momentach, które wspominam, odrzuciłem, czy rozerwałem zasłony pokrzepiających złudzeń, dzielących mnie od rzeczywistości, a za pomocą których usiłowałem czynić znośną moją egzystencję. Życie ukazało mi nagle przerażającą twarz Meduzy, a jej fascynująca moc wydawała się podporządkowywać sobie całą moją wolę rzetelności, całą przytomność umysłu czuwającego, by nie ulec złudzeniu. Jest to godzina tragicznego pesymizmu'

Kiedy złamany świat pokazuje nam swoją paraliżującą twarz, rodzi się w nas natychmiastowa pokusa, by w jakiś symboliczny sposób ściąć ową przeraża-

\footnotetext{
${ }^{5}$ G. Marcel Journal metaphysique, cyt. za: T. Terlecki, Krytyka personalistyczna. Egzystencjalizm chrześcijański, Warszawa 1987, s. 63.

${ }^{6}$ Tenże, Obecność i nieśmiertelność, tłum. K. Wróblewska, „W drodze” nr 11 (1977), s. 8.
} 
jącą głowę, odnaleźć zło, kryjące się w korzeniach tego monstrum, uczynić zeń pewien problemat, który dzięki dostępnym technikom i analizom będziemy mogli raz na zawsze rozwiązać. Zło, o którym mówił Marcel, nie jest jednak w ścisłym sensie tego słowa problemem. Jest tajemnicą. „Tajemnica jest czymś - pisał Marcel - w czym ja sam jestem zaangażowany i co w konsekwencji daje się pomyśleć wyłącznie jako sfera, w której rozróżnienie tego, co jest we mnie i tego, co jest przede mna, traci swe znaczenie i wartość pierwotną" Wynika z tego, że zło jest jakoś wrośnięte w każdego z nas. „W rzeczywistości nie uchwytuje się zła inaczej - uważał filozof - jak tylko o tyle, o ile mnie ono dosięga, to znaczy o ile jestem w nie wplątany w takim znaczeniu, jak bywa się wplątanym w jaką̧ś sprawę"8. W miarę postępu uczciwej refleksji dojść można do smutnego skądinąd wniosku, że nieład, który obserwuje się w świecie zewnętrznym, jest ostatecznie jakimś ,nieładem mnie samego" . Objawów zaś piekła jako kwintesencji zła człowiek powinien wypatrywać i ścigać w głębi samego siebie ${ }^{10}$. Nie można zatem wyobrazić sobie sytuacji, w której zło stanie zupełnie na zewnątrz nas. Według Marcela zło nigdy nie stanie się samym tylko problemem. W parze z tym przekonaniem idzie drugie, że świat nasz nie jest złamany historycznie, lecz istotowo ${ }^{11}$.

Istnieją sytuacje w życiu, kiedy to człowiek sam jest sprawcą zła, a zatem uczestniczy w jego pojawieniu się na świecie. Częstokroć wszakże jest i tak, że doświadcza go bez własnej winy. Wiele mówiąca może stać się wtedy postać Hioba. Zło może spaść na człowieka zupełnie niespodziewanie. Czasem dotyka go poprzez cierpienie jego samego lub bliskich mu osób. Kiedy indziej znowu przychodzi do niego jako lęk, który mówi mu, że nigdy w tym życiu od zła się nie uwolni. Nigdy nie będzie na tyle bezpieczny, by mógł powiedzieć, że przestało istnieć albo przestało na niego czyhać.

Dotyka się w ten sposób jednego z najbardziej rozpowszechnionych, ale też najpotężniejszych przejawów zła, jakim jest groźba. Człowiek bowiem nie musi bezpośrednio doświadczyć zła, by czuć się przez nie zagrożony. O jednej z takich przeżytych chwil zagrożenia pisał Marcel. „W ostatnich dniach można przeczytać w jego notatkach - niepokój wzrósł ponad miarę. Konferencja rozbrojeniowa zamiera. Incydent w Kehl, panuje tam terror. Istnieja chwile, w których żyję z uczuciem, że śmierć ciąży nad nami wszystkimi, nad

\footnotetext{
${ }^{7}$ Tenże, Być i mieć, s. 170.

${ }^{8}$ G. Marcel, Phenomenologie de l'avoir, cyt. za: E. Mukoid, Filozofia zła: Nabert, Marcel, Ricoeur, Kraków 1999, s. 113.

${ }^{9}$ E. Mukoid, Filozofia zła, s. 113.

${ }^{10}$ G. Marcel, Testament filozoficzny, thum. S. Grygiel, „Znak” XXVI (1974), s. 985.

${ }^{11}$ Tenże, Tajemnica bytu, s. 58.
} 
wszystkim, co kochamy" "12. Wydaje się także, że samo zło ma w człowieku sobie podporządkowane, ukryte i drzemiące siły, gotowe powstać przeciw niemu, gdy tylko nadchodzi groźba.

Rozproszone poczucie zagrożenia - czytamy w jednym ze świadectw francuskiego filozofa - które bierze się nie wiadomo skąd, niepewność [...]. Świadectwo moich zmysłów tak samo może okazać się złudne, jak złudne i niejasne okazuje się obiektywne rozgraniczenie tego, co przede mną, i tego, co we mnie, tego, co zagrożone, i tego, co zagraża ${ }^{13}$.

Osoba ludzka ma wtedy świadomość, że stoi naprzeciw tak potężnego wroga, wobec którego zawsze pozostanie ofiarą. Przeciwnika, który w tajemniczy sposób obezwładnia człowieka i jego wolę. Zmusza do bierności i poddania się przemożnym jego siłom.

Wobec tak zarysowanego zła rodzą się zupełnie naturalne pytania, czy aby Marcel nie wyznaje jakiegoś filozoficznego manicheizmu? Czy tak przedstawione zło nie jest uzasadnioną ze wszech miar racją naszej ludzkiej rozpaczy rozpowszechnionej właśnie w złamanym świecie? Czy postawa bierności nie jest jedyną rozsądną postawą, jaką może przyjąć człowiek, który zła doświadcza? Faktem jest, że Marcel używał wielkiej litery, pisząc o złu i jego tajemnicy. Odrzucał jednak możliwość jego hipostazowania ${ }^{14}$. Zaproponował on dla tej tajemniczej rzeczywistości „,neologizm de-natura, który zawierałby intuicję tajemnicy, zarazem jakiegoś rodzaju pozytywności (obecności) i absolutnej nieprzyswajalności, nieredukowalności, nieuchwytności dla nas, którzy z powodu naszej kondycji zmuszeni jesteśmy pozostać w tym, co częściowe" 15 . Wydaje się także, że pomimo swoistej grozy w opisywaniu zła Marcel daleki był od akceptowania rozpaczy i postawy bierności wobec niego. Cały następny podrozdział będzie próbą ukazania możliwości przeciwstawiania się złu, którego wpływ ujawnił się najbardziej właśnie w rzeczywistości pękniętego świata.

Pęknięcie owo, jak wspomniano, dotyczy w szczególności, choć nie wyłącznie, świata ludzkiego. To w nim osoba ludzka została dotknięta niemocą samotności duchowej, w nim także skażone zostały relacje międzyludzkie. Na tymże aspekcie człowieczego złamanego świata warto się teraz skupić. „Wszystkie utwory dramatyczne Marcela - pisał jeden z komentatorów jego myśli - można by określić jako dramaty samotności duchowej, a całą jego

\footnotetext{
${ }^{12}$ G. Marcel, Być i mieć, s. 206.

${ }^{13}$ E. Mukoid, Filozofia zła, s. 119.

${ }^{14}$ Tamże, s. 121.

15 Tamże, s. 127.
} 
filozofię, jako filozofię przezwyciężania samotności duchowej"16. Samotność ta jest odwrotnością samotności na przykład świętego pustelnika, który $\mathrm{w}$ swej celi pielęgnuje ideał komunii ze wszystkimi istotami ludzkimi. Tutaj, odwracając słowa Thomasa Mertona, każdy jest samotną wyspą. „Każdy jest sam" ${ }^{17}$. Nie może być mowy o wspólnocie, która ze swej natury przekracza indywidualistyczny egocentryzm.

Człowiek egocentryczny zaś postrzega sam siebie jako swego rodzaju enklawę ${ }^{18}$. „Ciążąc sam sobie - pisał Marcel - pogrążony w niepokojącym świecie zewnętrznym, to zagrażającym mi, to znów współwinnym, czujnie wypatruję wszystkiego, co emanując z niego, koić by mogło lub - przeciwnie - jątrzyć tę ranę, którą noszę w sobie: moj e j a"19. Osoba taka uwięziona jest we własnym tylko sposobie postrzegania świata oraz zamknięta będzie na wszelki dialog. Odrzuca każdą próbę otwarcia i przyjęcia w siebie perspektywy drugiego człowieka. Człowiek ten w ostateczności dokonuje „,aktu zamknięcia się w sobie lub uznania siebie za centrum"20.

Podobnie - pisał filozof w innym miejscu - jak wbrew wiadomościom kosmograficznym zachowujemy bezpośrednio wrażenie, że słońce i gwiazdy obracają się dokoła ziemi, tak nie jesteśmy w stanie uwolnić się całkowicie na tym świecie od przeświadczenia skłaniającego nas do traktowania siebie jako centrum, wokół którego wszystko się obraca i nie może się nie obracaćéc.

W tym miejscu do głosu dochodzi też fałszywe upodobanie w sobie i autogloryfikacja, której konsekwencje będą kłaść się cieniem na relacjach międzyludzkich.

Samotność w pękniętym świecie cechuje się bowiem także świadomością drugiego człowieka jako tego, który nas podgląda, osądza, zawstydza i nam zagraż $^{22}$. W tym sensie $\mathrm{j}$ a rozpoznaje się $\mathrm{w}$ drugim o tyle, o ile jest on intruzem, bo zagraża on całemu światu j a i jego wolności. $Z$ jednej strony istnieje egocentryczna samotność oparta na fałszu i złudzeniu bezwzględnej izolacji oraz niewspółmiernej wobec każdej innej jednostki ważności własnego j a. Z drugiej świadomość innego, który ingeruje w nasz egocentryczny i samowystarczalny świat zwykłym swoim byciem lub tylko spojrzeniem. Świa-

\footnotetext{
${ }^{16}$ T. Terlecki, Krytyka personalistyczna, s. 59.

${ }^{17}$ G. Marcel, Chapelle ardente, cyt. za: T. Terlecki, krytyka personalistyczna, s. 60

${ }_{18}^{18}$ Tenże, Homo viator, thum. P. Lubicz, Warszawa 1959, s. 13.

${ }^{19}$ Tamże, s. 13.

${ }^{20}$ G. Marcel, Tajemnica bytu, s. 385.

${ }^{21}$ Tenże, Homo viator, s. 19.

${ }^{22}$ Tamże, s. 257-259. Marcel w tej części książki referuje stanowisko Sartre'a zawarte w dziele Byt i nicość.
} 
domość uwięziona $\mathrm{w}$ j a nie może pojmować istnienia drugiego $\mathrm{w}$ innych kategoriach, jak tylko w kategoriach konfliktu. „Piekło to inni” - powiada w jednej ze swoich sztuk Sartre i musi to być ostateczna konkluzja wyprowadzona z filozofii osoby w rozbitym świecie. Jego (Sartre'a) człowiek jako byt w sobie oznacza totalną niemożliwość zrozumienia pojęć takich, jak przyjaźń czy miłośśc ${ }^{23}$.

To właśnie miłość jest najbardziej doniosłym wydarzeniem w życiu ludzi, którzy się autentycznie spotkali. W świecie jednak, którego serce przestało bić, prawdziwe spotkanie jest niemożliwe. Istnieją zamiast tego zetknięcia się ze sobą, mające na celu manipulacje lub techniczne wymiany zdań. Mija się też ludzi, ledwo zdając sobie sprawę $\mathrm{z}$ ich istnienia ${ }^{24}$. Nawet jeśli istnieje jakieś my, to nie ma w nim nic oprócz fizyczności. „Jest to my obojętności, w którym nikt nie jest kimś, nikt bowiem nikogo nie interesuje" ${ }^{25}$. Spotkanie zaś umożliwiające zarówno przyjaźń, jak i miłość, możliwe jest tylko tam, gdzie głębia j a otwarta jest na wymiar duchowy i niepowtarzalność istnienia drugiego człowieka, do którego mówię ty.

Konsekwencją braku autentycznych i głębokich spotkań w złamanym świecie będzie brak możliwości powstania takiego fenomenu, jakim jest wspólnota. To właśnie w niej ludzie mogliby czuć się nawzajem siostrami i braćmi. Analizując powyższą sytuację, Marcel zauważył bardzo ciekawą rzecz z punktu widzenia metafizyki braterstwa. „Szczególnie łatwo jest dostrzec - pisał on - że wszelkie braterstwo wiąże się z wyobrażeniem ojca i nie da się go w rzeczywistości oddzielić od powoływania się na transcendentny Byt, który mnie stworzył, który nas, ciebie i mnie stworzył. Ale właśnie tutaj pojawia się brak"26. W złamanym świecie robi się wszystko, by obraz Boga, owego transcendentnego Bytu został zniekształcony i zdyskredytowany. Jednakże bez tego koniecznego, jak się zdaje, odniesienia wspólnota braterska, którą winno być społeczeństwo, przeradza się w swoją własną karykaturę ${ }^{27}$. W niej to zamiast Boga umieszcza się kult państwa, partii bądź wodza. Tak czy inaczej rozpoczyna się ruch, w którym osobowość ulega atomizacji i funkcjonalizacji. Człowiek jest kimś przez wzgląd na swoją jednostkowość (tłum składa się z jednostek, których im więcej, tym lepiej) lub przez

${ }^{23}$ G. Marcel, Tajemnica bytu, s. 238.

${ }^{24}$ Tamże, $157-158$.

${ }^{25}$ W.A. Luijpen, Fenomenologia egzystencjalna, tłum. B. Chwedeńczuk, Warszawa 1972, s. 252 .

${ }^{26}$ G. Marcel, Tajemnica bytu, s. 55.

${ }^{27}$ P. Evdokimov, Gogol i Dostojewski, czyli zstapienie do otchtani, thum. A. Kunka, Bydgoszcz 2002, szczególnie rozdział: „Biesy - Fenomenologia ateizmu i eschatologia zła”. 
swoją funkcję w społecznej maszynie (komisarz ludowy będzie na wyższym miejscu od szeregowego posiadacza legitymacji partyjnej).

Końcowym akordem egzystencjalnym w złamanym świecie będzie panujące w nim poczucie rozpaczy. „Według Marcela - pisał Karol Tarnowski przed człowiekiem otwiera się zawsze możliwość rozpaczy i nic nie jest jej w stanie raz na zawsze egzorcyzmować" ${ }^{28}$. Rozpacz jest, jak się zdaje, wartością negatywną w stosunku do swego pozytywnego odpowiednika - nadziei. Więcej nawet. „Jest ona wyraźnie wroga - jak zauważył inny polski filozof do swego pozytywnego bieguna. Sensem swym nie tylko zaprzecza wartości pozytywnej, nie tylko jest jej przeciwieństwem, ale zdecydowanie wrogim przeciwieństwem" ${ }^{29}$. Rozpacz oznaczać może zatem agresywną u swego podłoża, negatywną rzeczywistość. I rzeczywiście, przypatrując się fenomenowi rozpaczy, można stwierdzić, że nie „zadowala się” ona współistnieniem z nadzieją. W przestrzeni rozpaczy atakowane są jej najbardziej subtelne przejawy. Łatwo to zauważyć u człowieka niejako porażonego rozpaczą. Wszelkie odruchy nadziei u innych będą go drażniły i prowokowały do agresji. Przybierać ona może oczywiście wiele różnych form: ośmieszania, drwiny, dyskredytacji, podkopywania podstaw nadziei u innych itp.

Istotą rozpaczy według Marcela jest ,zawsze kapitulacja przed czymś, co mój sąd uznał za fatu m"30. Kapitulacją zaś nie jest uświadomienie sobie pewnego faktu. Nie będzie nią też przyjęcie do wiadomości jakiegoś ważnego dla mnie i - być może - bolesnego wydarzenia, traktowanego jako zrządzenie albo wyrok losu. „Jest to załam anie się - pisał on - w obliczu tego wyroku, w obliczu nieuniknionego: jest to $\mathrm{w}$ istocie zrezygnowanie $\mathrm{z}$ pozostania sobą samym, zafascynowanie ideą własnego zniszczenia do tego stopnia, że się je wyprzedza"31. Towarzyszy temu poczucie lęku, napięcia i wewnętrznej niecierpliwości wobec przeżywanej rzeczywistości. Owa rzeczywistość jawi się wtedy człowiekowi jako jednolicie wroga lub zupełnie obojętna przestrzeń, w której nie ma już nic, czemu duch ludzki mógłby zaufać.

„Rozpacz - czytamy też u Marcela - to w pewnym sensie świadomość zamkniętego czasu lub, ściślej mówiąc, uświadomienie sobie czasu jako więzienia, podczas gdy nadzieja zdaje się przenikać poprzez czas"32. Ów zamknięty czas to życie człowieka w świecie, w którym nic się już nie wydarzy.

\footnotetext{
${ }^{28}$ K. Tarnowski, Gabriel Marcel, filozof próby, w: G. Marcel, Tajemnica bytu, s. 21.

${ }^{29}$ A. Siemianowski, Człowiek a świat wartości, Gniezno 1993, s. 80.

${ }^{30}$ G. Marcel, Homo viator, s. 45-46.

${ }^{31}$ Tamże, s. 47.

${ }^{32}$ Tamże, s. 71-72.
} 
W świecie, w którym nic go już nie wzywa do działania, a więzy łączące go z innymi zerwały się. Człowiek taki pogrążony w coraz to uciążliwszym marazmie i bezczynności wypatruje już tylko śmierci jako jedynego wybawienia. Marcel zauważył ciekawą rzecz dotyczącą związku rozpaczy z bezczynnościa. ,Rozpacz bowiem - pisał - nie jest niczym innym jak bezczynnością, która osiagnęła najbardziej wyostrzoną świadomość samej siebie, jest - by użyć tu nieco barbarzyńskiego słowa - brakiem zaangażowania [...], dezercją świadomości, która utraciła już łączność z rzeczywistością"33. Owa dezercja ma wiele wspólnego z samobójstwem, które to (pomijając niektóre wypadki) jest konsekwencją duchowego zerwania więzów ze wspólnotą ludzką i rzeczywistością.

Rozpacz w swym ostatecznym wyrazie jest ludzką kapitulacją wobec faktu śmierci. Jej nieodwołalność przynosi człowiekowi groźbę niebytu. W tym miejscu daje się zauważyć jedną z najistotniejszych konsekwencji ideologii pękniętego świata. Odrzuca się w niej samą możliwość istnienia Boga, a w rezultacie i nieśmiertelność. Śmierć jest tam absolutnym końcem, od którego nikt i nic nas nie wybawi ${ }^{34}$. Człowiekowi odmawia się w nim właśnie nadziei, rozpacz zaś nobilituje się jako jedynie godną człowieka postawę. Postawę prawdziwie ludzką. ,Zamiast karmić się złudzeniami co do wieczności - pisał jeden z przedstawicieli filozofii złamanego świata - umysł absurdalny raczej niż na kłamstwo zgodzi się bez drżenia na odpowiedź Kierkegaarda «rozpaczą». W końcu dusza zdecydowana na wszystko zawsze da sobie z nią radę"35.

Rozpacz może i rozprzestrzenia się w złamanym świecie, gdyż stał się on, na mocy przyjętej przez siebie dogmatycznej ideologii, heroldem ostatecznego panowania śmierci. Jej nieuchronność, dzięki jednostronnej interpretacji jako definitywnego końca, spowodowała odrzucenie każdej możliwej nadziei, mającej swoje uzasadnienie wybiegające poza śmierć. Wydaje się jednak, że w tym miejscu filozofia pękniętego świata rości sobie prawo do wyciągania absolutnych wniosków z rzeczywistości, która jest i pozostanie tajemnicą. „Jeśli śmierć jest milczeniem - pisał Marcel - to nie potrafimy wyznaczyć jego granicy, gdyż nie wiemy, co ono w sobie kryje, czego strzeże, co może przygotowuje. Sofizmat - zdrada - polega na interpretowaniu tego milczenia jako nieistnienia, jako popadnięcia w niebyt" ${ }^{\prime 3}$. Rozpacz jest i pozostanie na

\footnotetext{
${ }^{33}$ Tamże, s. 212.

${ }^{34}$ K. Tarnowski, Ku absolutnej ucieczce, Kraków 1993, s. 78.

${ }^{35}$ A. Camus, Mit Syzyfa i inne eseje, thum. J. Guze, Warszawa 2004, s. 98.

${ }^{36}$ G. Marcel, Homo viator, s. 217.
} 
zawsze pokusą, która może być jednakże przezwyciężana poprzez uciekanie się do miłości i zbudowanej na niej komunii osób oraz poprzez uciekanie się do nadziei ${ }^{37}$.

\section{POTRZEBA PRAWDY}

Dotychczas, przy okazji omawiania rzeczywistości pękniętego świata wspominano o nadziei. Uciekanie się do niej oraz uciekanie się do komunii miałoby pomagać człowiekowi w odrzucaniu pokusy rozpaczy. Na pierwszy rzut oka wydaje się więc, że odpowiedniejszym tytułem całego tego artykułu mogłyby być sentencje, w których właśnie nadzieja, miłość bądź komunia występowałyby w roli decydujących i pomocnych nam, ludziom, czynników w walce z rzeczywistością pękniętego świata. Bez wątpienia znajdują się one w samym centrum tejże walki. Niemniej jednak istnieje także, nierzucająca się bezpośrednio w oczy w refleksji Marcela, głęboka potrzeba, która związana jest nie tylko z podstawą naszej nadziei, ale też z podstawą naszej miłości i powstałej na jej fundamencie komunii osób. Jest nią właśnie potrzeba prawdy.

Występuje ona przede wszystkim jako wyjątkowa ludzka zdolność rozpoznawania tajemniczego światła prawdy i zbliżania się do niego pośród wydarzeń codziennego życia. Owa zdolność wyraża się poprzez specyficzny niepokój, który Marcel nazwał niepokojem metafizycznym ${ }^{38}$. Nie jest on ciekawością, gdyż ta zawsze odwodzi człowieka od jego centrum i prowadzi go ku peryferiom osobowości. „Niepokój - pisał on - jest tym bardziej metafizyczny, im bardziej dotyczy tego, czego nie można oddzielić od mojego «ja», nie powodując jednocześnie unicestwienia owego «ja» [...]. Jest to niepokój właściwy nam wszystkim" "39. Dotyczy on zatem każdego ludzkiego ducha, który jako taki wykazuje niepewność swojego własnego statusu bytowania. „Niepokój metafizyczny - czytamy - może ustąpić jedynie dzięki poznaniu. O jakie poznanie jednak może tu chodzić? Metafizyk zdawałby się przeczyć samemu sobie, gdyby nie głosił, że nie szuka «prawdy»" ${ }^{40}$. Ostatecznie więc Marcel wykazuje, że ów głęboko odczuwany niepokój jest w nas pragnieniem, potrzebą, która uzyskuje spełnienie jedynie w prawdzie.

Prawda jednak, o którą tutaj chodzi, nie ma nic wspólnego z prawdami szczegółowymi, znanymi z nauk przyrodniczych. W odróżnieniu od nich

${ }^{37}$ Tamże, s. 82.

${ }^{38}$ Tamże, s. 200.

${ }^{39}$ Tamże, s. 201-202.

${ }^{40}$ Tamże, s. 202. 
Marcel mówił raczej o duchu prawdy. „Prawda - pisał on - jest to na pewno pierwsze $\mathrm{i}$ ostatnie słowo, jest to alfa i omega, [...] która nie jest rzeczą, lecz duchem” ${ }^{41}$. „Duch prawdy - czytamy w innym miejscu - niewątpliwie pokrewny natchnieniu, może nas przenikać na kształt wiązki światła"42. Francuski myśliciel używał wielu przybliżeń ukazujących tajemniczą postać prawdy. Żadne $\mathrm{z}$ nich nie jest bez znaczenia w kontekście całej jego twórczości. Trzeba jednak, choćby ze względu na ograniczoną objętość tego tekstu, skupić się na jej najistotniejszych cechach. Wydaje się, że przybliżenie prawdy od strony jej powiązania $\mathrm{z}$ kondycją ludzką ${ }^{43}$ oraz przybliżenie prawdy jako wartości okaże się najbardziej odpowiednie dla naszego zamierzenia. Prawda bowiem, związana z kondycją ludzką, ukazuje człowiekowi jego właściwe miejsce w świecie. Natomiast prawda jako wartość oświetla ludzkie drogi od wewnątrz, niejako je uświęca, wskazuje także kierunek i cel tych dróg. Warto może jedynie dopowiedzieć, że w filozofii Marcela duch prawdy jako żywa rzeczywistość wymykał się wszelkim próbom unieruchomienia go w jakimkolwiek systemie filozoficznym.

„Kto wie - pisał o kondycji ludzkiej Marcel - czy trwały porządek ziemski nie może być wprowadzony tylko pod tym warunkiem, że człowiek zachowa wyraźną świadomość tego, co można by nazwać jego kondycją pielgrzyma" ${ }^{44}$. W tym wyznaniu francuski filozof dotyka dwóch spraw. Po pierwsze, trwały porządek ziemski jest wyraźną opozycją do pękniętego świata, którego opis znalazł się na początku artykułu. Jest to porządek, w którym wartości takie, jak dobro, prawda czy piękno, mają swoje nieredukowalne znaczenie. To rzeczywistość wypełniona prawdziwą ludzką obecnością oraz relacjami przyjaźni i miłości. Po drugie, prawda o kondycji ludzkiej stoi tu właśnie na straży owego porządku. Kondycja pielgrzyma, o której mowa, to z pewnością otwarty na nieśmiertelność duch ludzki, który nie uznaje nad sobą ostatecznej władzy rzeczywistości doczesnej i śmierci.

W złamanym świecie filozofowie egzystencjalni o orientacji ateistycznej, w tym Sartre i Camus, głosili dokładnie coś przeciwnego ${ }^{45}$. W ich opinii to właśnie „złudzenie zaświatów” czyni człowieka bezwolnym i gnuśnym w tym świecie. Natomiast oddanie się wyłącznie rzeczywistości ziemskiej miałoby przywrócić człowiekowi jego prawdziwą godność i wolność. Poglądy tego

${ }^{41}$ G. Marcel, Tajemnica bytu, s. 228.

${ }^{42}$ Tenże, Homo viator, s. 205.

${ }^{43}$ Tamże, s. 204

${ }^{44}$ Tamże, s. 225.

45 J.-P. Sartre, Egzystencjalizm jest humanizmem, thum. J. Krajewski, Warszawa 1998, s. 33-34; A. Camus, Mit Syzyfa i inne eseje, s. 68, 76. 
typu są według Marcela kuszące, lecz rzeczywistość, jaka się za nimi kryje, pokazuje zupełnie inny świat. Nie pełen ludzi wolnych i świadomych swojej godności oraz godności innych osób, ale coraz bardziej sfunkcjonalizowany świat jednostek. Jest to zatomizowana rzeczywistość, w której pierwszoplanowe role odgrywają: samotność, rozpacz i poczucie absurdalności życia. „W świecie pełnym zgorszenia - oponował Marcel wobec «metafizyków ziemi» - w którym ostatecznie zwyciężałby absurd, a więc, w którym to, co najlepsze i najwznioślejsze, byłoby zdane na łaskę ślepych sił [...] nie istniałaby ani jedna wartość, której nie można by uważać za śmieszną i podejrzaną"46.

Bazując tylko i wyłącznie na doczesności, nie sposób, jak widać, odnaleźć w niej uzasadnień dla życia wartościami.

W warunkach naszego życia na ziemi - Marcel cytował fragment książki Prousta nie ma racji po temu, byśmy czuli się zobowiązani do czynienia dobra, do delikatności czy uprzejmości; nie istnieją one również dla artysty, który odczuwa konieczność, by po dwadzieścia razy rozpoczynać od nowa jakiś utwór, choć zachwyt, jaki to dzieło wzbudzi, nie będzie miał już większego znaczenia dla jego ciała toczonego przez robaki [...]. Wszystkie te zobowiązania, które nie znajdują uzasadnienia w obecnym życiu, zdają się należeć do innego świata, opartego na dobroci, delikatności i poświęceniu, do świata, który opuszczamy, by narodzić się na tej ziemi, a do którego może później powrócimy, aby odżyć pod panowaniem tych nieznanych praw, którym byliśmy posłuszni, gdyż nosiliśmy w naszym wnętrzu ich nakazy, nie wiedząc, kto je tam wyrył, tych praw, do których nas przybliża wszelka głębsza praca rozumu ${ }^{47}$.

Odkryta tutaj intuicja przywołuje nie tylko koncepcję Platona, ale także ruch myśli na tyle odważnej, by na poważnie podjąć ryzyko wiary w nieśmiertelność.

To właśnie w człowieku gotowym to ryzyko podjąć dochodzi do głosu wierność duchowi prawdy. W człowieku, który „,będzie stale pamiętał o konieczności wykuwania sobie niepewnej drogi poprzez eratyczne głazy upadłego wszechświata, wymykającemu się pod każdym względem samemu sobie, ku światu bardziej umocnionemu w bycie, ku światu, którego jedynie zmienne i niepewne odblaski można dostrzec z ziemi”48. Marcel wcale nie przeczy, że afirmowanie rzeczywistości pozaziemskiej zawiera w sobie ryzyko. Uważa jednak, a trzeba dodać, że w złamanym, sfunkcjonalizowanym świecie ma do takiego poglądu podstawy, iż odrzucenie tegoż ryzyka doprowadzić może rzeczywistość ziemską do zguby ${ }^{49}$.

${ }^{46}$ G. Marcel, Homo viator, s. 224.

${ }^{47}$ Tamże, s. 2.

${ }^{48}$ Tamże, s. 225.

${ }^{49}$ Tamże, s. 226. 
Prawda dotycząca kondycji ludzkiej ukazuje jej ukierunkowanie na nieśmiertelność. Przybliża jednak także rzeczywistą wartość osoby ludzkiej. W pękniętym świecie bowiem ocena wartości człowieka ulega dwóm skrajnościom. $Z$ jednej strony traktuje się go jako społeczną funkcję, element, tryb ${ }^{50}$, a przez to odrzuca się jakąkolwiek wartość osoby jako takiej. Z drugiej stara się mu wmówić, że to człowiek właśnie powinien zająć miejsce $\mathrm{Boga}^{51}$. Prawda o człowieku według Marcela chroni go przed tymi skrajnościami. Tak samo oddalona od poniżonej świadomości funkcjonalnej, jak i od bałwochwalstwa.

Osoba - pisał Marcel - uczestniczy w niewyczerpalnej pełni bytu, z którego sama się wyłania. W tym tkwi głęboka przyczyna, dla której nie można pojąć osoby ani porządku osobowości w oderwaniu od tego, co jest poza nią i poza nim - w oderwaniu od rzeczywistości ponadosobowej, która kieruje wszystkimi jej poczynaniami i jest zarazem jej początkiem i jej końcem ${ }^{52}$.

Pełnia bytu, którą na innym miejscu francuski filozof nazywa Bogiem, jest tą przestrzenią, do której człowiek winien się odnosić, chcąc uzyskać wgląd W prawdę o sobie. W ten sposób, nieustannie przekraczając siebie ku transcendencji Boga, osoba uzyskuje właściwą sobie godność, godność pochodzenia oraz godność ostatecznego celu. Według Marcela zawołanie osoby będzie brzmiało sursum, nie zaś sum ${ }^{53}$.

Jak widać, prawda o człowieku jest nieodłączna od rzeczywistości Boga. To On właśnie został odrzucony za margines pękniętego świata jako ten, który zagraża wolności człowieka. Okazuje się jednak, że odrzucenie Boga godzi w samego człowieka i podstawowe relacje społeczne. „Gdy człowiek, zaprzeczając istnieniu Boga - czytamy w eseju Tajemnica rodziny - przeczy samemu sobie, siły duchowe, jakie wyzwala jego wyparcie się... mogą już tylko zwrócić rozpaczliwie przeciw sobie istoty złożone z ciała i duszy"54. Dostojewski napisał w Braciach Karamazow znane słowa, ,jeśli nie ma Boga, to wszystko jest dozwolone". Pomimo nieustającej wręcz krytyki prawdziwości tejże sentencji, jest ona coraz bardziej spełniającym się proroctwem rosyjskiego pisarza. Nie dlatego - bo na to z reguły zwracają uwagę oponenci - że człowiek sam z siebie nie może postępować etycznie, ale dlatego, że właśnie wtedy otwiera się przed człowiekiem możliwość postępowania nieetycznego,

\footnotetext{
${ }^{50}$ G. Marcel, Homo viator, s. 24.

${ }^{51}$ Tenże, Tajemnica bytu, s. 54-55.

52 Tenże, Homo viator, s. 29.

53 Tamże, s. 28.

54 Tamże, s. 136.
} 
pozbawionego fundamentów. Z tej to możliwości, jak pokazuje historia, człowiek skwapliwie korzysta. Etyka ograniczona do ludzkiego tylko pojmowania świata ulega i ulegać będzie antynomiom ludzkiego rozumu. Przykłady totalitaryzmów XX wieku są tego wyraźnym świadectwem. Istotna też część współczesnej etyki daje się wpisywać w tę dowolność bez Boga ${ }^{55}$.

Człowiek, jakim widzi go Marcel, nie może w pełni odnaleźć prawdy o sobie bez odniesienia do Boga. Jednak nie może jej także odkryć w samotności, jako monada. Wmówienie człowiekowi, że jest on tak naprawdę sam, odgrodzony od innych nieprzekraczalną granica uważa francuski filozof za jedno z najniebezpieczniejszych kłamstw w historii myśli ludzkiej. Na tle takiej tylko filozofii mogło powstać powiedzenie Sartre’a, że „,piekło to inni”. Egocentryzm reprezentowany jako arcynaturalny w złamanym świecie w optyce Marcela uzyskuje status pewnego osobowego i duchowego braku. „Im wyższy osiągam poziom - pisał on - naprawdę konkretnego postrzegania mojego własnego doświadczenia, tym bardziej właśnie dzięki temu jestem w stanie osiagnąć rzeczywiste zrozumienie kogoś drugiego, doświadczenia kogoś drugiego" ${ }^{56}$. Egocentryzm człowieka jest swego rodzaju ślepota, która poprzez skupienie wyłącznie na samym sobie wypacza swój obraz. Zapoznaje swoje prawdziwe potrzeby i swoją prawdziwą wartość.

Prawdziwa samoświadomość zawsze będzie oparta na relacyjności. „Nie jesteśmy - wręcz apeluje Marcel - dla siebie samych" ${ }^{57}$.

Jedynie rozpoczynając od drugiego albo drugich - czytamy na innym miejscu - jedynie rozpoczynając od nich, możemy zrozumieć samych siebie [...]. Jedynie pośrednictwo kogoś drugiego może dawać podstawy do miłości samego siebie, jedynie ono może uodpornić tę miłość na niebezpieczeństwo egocentryzmu i zapewnić jej rozumny charakter, który w przeciwnym razie nieuchronnie traci ${ }^{58}$.

Osoba uczestniczy w prawdzie o sobie, ale także w prawdzie bytu jako otwartość na wspólnotę. Właśnie Marcelowska „metafizyka pewnego jesteśmy” przeciwstawia się tutaj metafizyce wywodzącej się z Kartezjańskiego: cogito ergo sum. Byt w swojej głębi, jak się zdaje, jest wewnętrznie powiązany

${ }^{55}$ Głównym teoretykiem takiej etyki stał się w naszych czasach australijski filozof Peter Singer, szczególnie w książce Etyka praktyczna. Wydaje się, że możliwość, otwierająca się przed człowiekiem po odrzuceniu Boga, jest równią pochyła, po której naturalnie zsuwa się on poniżej poziomu człowieczeństwa, który to poziom początkowo przyświecał właśnie idei odrzucenia Boga. Ponadto etyka bez Boga poddana jest wszelkim niedoskonałościom ludzkiego myślenia, żeby wspomnieć tylko o prawie do błędu.

${ }^{56}$ G. Marcel, Tajemnica bytu, s. 236.

57 Tenże, Być i mieć, s. 166.

${ }^{58}$ Tenże, Tajemnica bytu, s. 237. 
z intersubiektywnością wspólnoty. Stanowi on jej podłoże, ale także potencjalną tej wspólnoty pełnię. „Troszczę się o byt - konkluduje Marcel - tylko o tyle, o ile bardziej lub mniej uświadamiam sobie ukrytą jedność, łączącą mnie z innymi bytami, których rzeczywistość przeczuwam"59.

W tym właśnie odniesieniu do bytu i do jego połączenia z intersubiektywnością ludzkiej wspólnoty pokazuje się prawda jako wartość. Marcel uważał bowiem, że wartość i byt są w tajemniczy sposób połączone ${ }^{60}$. Prawda zaś byłaby jakby radością przebywania w przepełnionej światłem wspólnocie ludzkiej, nazwanej przez Marcela środowiskiem inteligibilnym ${ }^{61}$. W tym to środowisku dokonuje się między ludźmi wzajemny przepływ, komunikacja. Ludzie zaś w nim są zdolni do przekraczania swoich egocentrycznych upodobań na rzecz prawdziwości owej komunikacji. „Czy nie mamy podstaw pytał retorycznie Marcel - wyobrażać sobie, że to, co nazywamy miłością do prawdy, może być pewnego rodzaju tajemniczą radością z poruszania się w tym środowisku - radością zresztą nietrwałą, radością zagrożoną?"62 Wartość ta jako antycypacja w radości mogłaby ukierunkowywać nasze ludzkie poczynania i w ten sposób upodobniałaby się do objawiającej się już w naszych ziemskich warunkach obietnicy.

Właściwością wartości - pisał o duchu prawdy filozof - jest w istocie rzeczy spełnianie pewnej funkcji w stosunku do życia i jak gdyby wyciskanie na nim swego piętna [...]. Jeżeli poświęcam życie służbie dla jakiejś sprawy, w której jakaś wyższa wartość wchodzi w grę, tym samym moje życie otrzymuje od tej wartości uświęcenie wyłączające je spod zmiennych kolei historii ${ }^{63}$.

Prawda zatem jako wartość miałaby cechę rzeczywistości sakralnej zdolnej swemu wyznawcy udzielić święceń. Wartość ta realizuje się w życiu ludzkim nie inaczej, jak poprzez ciaggle ponawiane próby walki z tym, co Marcel określa mianem łatwizny i upodobaniem $w$ sobie $^{64}$. Ma ona także, jak widać, cechę stawki w grze, którą człowiek prowadzi najczęściej z samym sobą. Wartość prawdy ma wtedy możność przybliżenia człowiekowi samego siebie ${ }^{65}$. W tym sensie duch prawdy w ujęciu Marcela zbliża się do Boga, o którym święty Augustyn powiedział, że jest On bliższy nam niż my sami ${ }^{66}$. To praw-

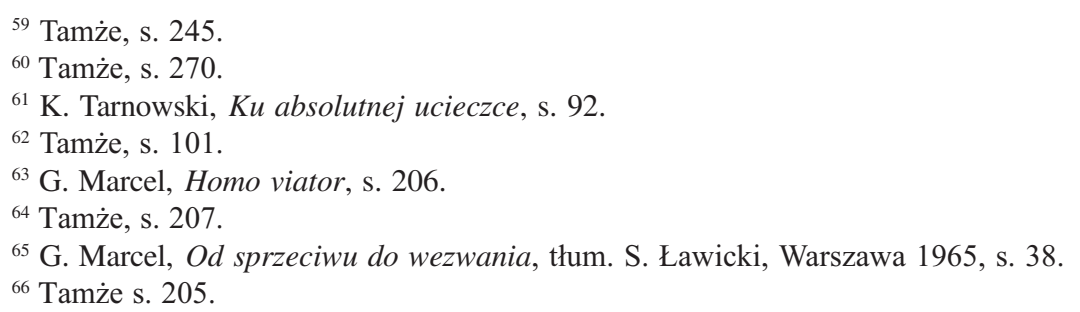


da właśnie jako wartość ukazuje człowiekowi, że wysiłek, do którego jest on wezwany, aby być wierny duchowi prawdy, jest tego wart. Wartość tego wysiłku przekracza nie tylko sferę ziemskiej ekonomii i opłacalności, wprowadza bowiem człowieka na płaszczyznę, w której może on uczestniczyć w symfonii życia, która jest Bogiem samym ${ }^{67}$.

Wszystko, co zostało powiedziane dotychczas, przygotowało miejsce dla innej wartości, tej, której cicha obecność wplatała się w nasze rozważania. Mowa oczywiście o nadziei, która według Marcela jest z istoty swej „cicha i skromna, jak gdyby naznaczona niezatartym piętnem nieśmiałości”'68. Jest nią także owa obecna wśród nas potrzeba prawdy, otwarcie na nią, ale także niezgoda na kłamstwo i powierzchownie przeżywane życie. Taka nadzieja ukazuje się nam nie tyle pomimo realizmu złamanego wewnętrznie świata, ale jakby właśnie dlatego, że ten świat nam ciąży. „Im mniej odczuwamy życie jako niewolę - pisał Marcel - tym mniej dusza jest wrażliwa na blask owego zamglonego tajemniczego światła, które płonie w samym ognisku nadziei" ${ }^{69}$. Gdzie bowiem bardziej niż w złamanym świecie można odczuwać życie jako przedłużającą się w nieskończoność niewolę? Ludzka potrzeba prawdy odsyła do nadziei, gdyż zarówno prawda, jak i nadzieja w Marcelowskiej perspektywie są powiązane z pełnią bytu, która jest samym Bogiem.

Nadzieja daleka jest od życiowego optymizmu, który w dużej mierze opiera się na wierze w rozum i zdolności ludzkiego umysłu do rozwiązywania problemów. Optymizm załamuje się jednak w obliczu niepodważalnych faktów, takich jak nieuleczalna choroba czy śmierć. Nadzieja zaś przekracza fakty. Nie może skapitulować przed nimi, gdyż jej otwartość transcenduje świat rzeczywistości widzialnej oraz skończoność. Dzięki wewnętrznemu połączeniu z pełnią bytu, ale także dzięki komunii między ludźmi nadzieja przekracza śmierć. Jej pewność jest iście prorocza. „Nie odnosi się ona do tego, co powinno być, czy nawet do tego, co ma być: mówi po prostu: to będzie" ${ }^{7}$. Teraz także widać, dlaczego Marcel tak duży nacisk kładzie na wspólnotę ludzką, na metafizykę owego j e s t e ś m y. We wspólnocie, w komunii między nami rodzi się nie tylko potrzeba prawdy, potrzeba podążania ku Temu, który jest jej ostatecznym gwarantem. Komunia osób jest ponadto jakby jedyną przestrzenią uprzywilejowaną, w której nadzieja może się począć. Prawdziwa nadzieja jest od tej komunii nieodłączna.

\footnotetext{
${ }^{67}$ G. Marcel, Tajemnica bytu, s. 390.

${ }^{68}$ Tamże, s. 67.

${ }^{69}$ Tamże, s. 38.

${ }^{70}$ G. Marcel, Być i mieć, s. 113.
} 
Dobrze będzie, jak się zdaje, zakończyć te refleksje definicją nadziei samego Marcela, pamiętając wszakże, że dzięki uczestnictwu w pełni bytu wstępuje ona w przestrzeń tajemnicy, której do końca w naszym świecie zgłębić nie możemy.

Nadzieja - pisał on - jest z istoty swej jak gdyby gotowością duszy zaangażowanej dostatecznie głęboko w doświadczenie komunii, by mogła dokonać aktu transcendentnego, odmiennego od aktu woli i poznania, którym to aktem stwierdza ona żywą wieczność; przy tym doświadczenie to stanowi jednocześnie rękojmię i przesłanki owej wieczności ${ }^{71}$.

Właśnie owa żywa wieczność jest naszej nadziei źródłem, jest także jej spełnieniem.

\section{SUMMARY}

Gabriel Marcel is known as a Christian existentialist and a philosopher of hope. Hope for human beings in the broken world is the main thesis of the article. Marcel introduced the idea of a broken world to philosophy as a negative in the moral sense, multidimensional notion that is directly related to our human world. According to Marcel, the root of the broken world is the mystery of evil. The broken world occurs everywhere where a human being is left alone without an authentic community, without brotherhood, without hope. However, even in the broken world there is hope for us. In the human soul Marcel discovered a mysterious sensitivity to the light of the truth and the deepest need for the truth. Those qualities of the human heart prove that it is possible for us to turn away from the broken world and to turn to the spirit of truth.

\section{Keywords}

Gabriel Marcel, broken world, evil, hopelessness, philosophy of hope, truth, faith, fidelity, God, community, communion

${ }^{71}$ Tegoż, Homo viator, s. 94. 